University of Wollongong

Research Online

Faculty of Law, Humanities and the Arts Papers (Archive)

Faculty of Arts, Social Sciences \& Humanities

$1-1-2013$

Do You See what I See? Iconic Art and Culture and the Judicial Eye in Australian Law

Marett Leiboff

University of Wollongong, marett@uow.edu.au

Follow this and additional works at: https://ro.uow.edu.au/lhapapers

Part of the Arts and Humanities Commons, and the Law Commons

Research Online is the open access institutional repository for the University of Wollongong. For further information contact the UOW Library: research-pubs@uow.edu.au 


\title{
Do You See what I See? Iconic Art and Culture and the Judicial Eye in Australian Law
}

\begin{abstract}
Law, as a practice, makes the claim that it deals in clear, verifiable and ascertainable facts and knowledge, eschewing the insensible, or what can only be 'felt' or 'sensed'. And this is the rub; what happens when the courts make decisions about visuals and images? What exactly do they see?

My purpose in this chapter is to explore how Australian courts, in a diverse set of circumstances, have 'seen' visuals or images, such as art or other cultural and creative outputs, and to propose a corrective to their empiricist reading of them, through the use of a Panofskian iconological schema. As in other jurisdictions, Australian courts have engaged in decision-making about matters typically relevant to images and visuals in disputes over copyright law, commercial transactions, blasphemy and taxation law. But for the purposes of this chapter, I explore how Australian judges 'see' visuals and images in areas of law concerned with, or draw upon, uniquely Australian experiences: in broadcasting law, cultural heritage law, and the trust establishing a famous annual portraiture prize featuring Australians - the Archibald Prize.
\end{abstract}

Keywords

era2015

Disciplines

Arts and Humanities | Law

\section{Publication Details}

M. Leiboff, 'Do You See what I See? Iconic Art and Culture and the Judicial Eye in Australian Law' in A. Wagner and R. K. Sherwin(ed), Law, Culture and Visual Studies (2013) 363-392. 


\title{
Do You See What I See? \\ Iconic Art and Culture and the Judicial Eye in Australian Law
}

\author{
Marett Leiboff \\ Legal Intersections Research Centre \\ Faculty of Law \\ University of Wollongong \\ Australia
}

\section{$1.1 \quad$ Talking to strangers}

Law, as a practice, makes the claim that it deals in clear, verifiable and ascertainable facts and knowledge, eschewing the insensible, or what can only be 'felt' or 'sensed'. And this is the rub; what happens when the courts make decisions about visuals and images? What exactly do they see?

My purpose in this chapter is to explore how Australian courts, in a diverse set of circumstances, have 'seen' visuals or images, such as art or other cultural and creative outputs, and to propose a corrective to their empiricist reading of them, through the use of a Panofskian iconological schema. As in other jurisdictions, Australian courts have engaged in decision-making about matters typically relevant to images and visuals in disputes over copyright law, commercial transactions, blasphemy and taxation law. But for the purposes of this chapter, I explore how Australian judges 'see' visuals and images in areas of law concerned with, or draw upon, uniquely Australian experiences: in broadcasting law, cultural heritage law, and the trust establishing a famous annual portraiture prize featuring Australians the Archibald Prize.

The examples provide extraordinary insights into the choices the courts make when looking at art. They show that the courts will acknowledge or occlude what is in front of them in ways that under or over read the visual in question, from focussing on literal identifiable physical minutiae on the one hand, while floridly embroidering national narratives associated with visuals on the other. The examples have been chosen because all deal with a very public vision of Australia, albeit one that is grounded in a mythologised and imaginary conception of an idealised Australia. The examples reveal a series of paradoxes that characterise the judicial reading of visual texts. Like other common law jurisdictions, the Australian courts ground their readings of visuals in empiricist analytical terms, which, it is claimed, will result in clear sighted decision-making in cases involving art or culture (Leiboff 2001). For this reason, ostensibly at least, they purport to avoid entering into questions concerning aesthetics in deference to art itself (Kirby 2006). Yet the courts maintain that they can tell 'what makes something art' or 'what makes some creative output recognisably Australian', despite such disavowals. So in the course of reaching a decision about whether an image was or was not painted, Harrison $\mathrm{J}$ in New South Wales Supreme Court could claim that: 'I do not think it goes outside the bounds of judicial knowledge, but is 
common knowledge, that line drawing is among the techniques used by painters in the course of creating paintings in the strictest sense'. ${ }^{1}$

\subsubsection{The juridical-aesthetic state of exception}

Examples of this kind reveal that law's claimed disengagement with the visual is weak and, as this chapter will reveal, latently corruptible (in the sense that perverse and peculiar readings of the visual and thus the law will result). The courts engage in readings that are fundamentally ascriptive (not descriptive as they would hope) that can result in a judicial reinscription of the image or visual itself (Douzinas and Nead 1999, Barron 2006, Leiboff 2006, 2007, 2009). Yet rather than achieve certainty in fact and law, the methods used by the courts are radically uncertain, able to vouchsafe only the elements or indicia certa used to that construct the visual. This leaves the visual, as rendered by law, in a juridical-aesthetic state of exception, able to be deployed and redeployed for the desired and desirable legal outcome, reflecting Richard Sherwin observations that 'Aesthetics isolated from some grounding in the ethical offers no protection against, and might even invite, a sense of law as being rooted in no more than subjective preferences, or perhaps the will to power alone' (Sherwin 2007, 71).

The idea that these judicial readings could be conceived as a juridical-aesthetic rendering of the politically grounded Schmittian state of exception may seem surprising, given that Schmitt asserted that the political and the aesthetic are radically distinct, opposing domains (Levi 2007, 33), and the state of exception is itself problematic. However, the state of exception as conceived by Schmitt functions in realms that 'cannot be circumscribed factually, made to conform to a preformed law, or be otherwise anticipated' (Levi 2007, 29). And this is precisely what happens when the courts read images: the object is discursively stripped of its narrative, and the empiricist eye of the naïve judicial everyman, or court as sovereign radically reconceives it for the purposes of legal interpretation. The resulting visual may bear no resemblance to its existence in other dimensions and other domains, or as conceived by its creator, but is now open to be deployed in aid of whatever legal purpose it needs to fulfil. By treating visuals and images as 'rule-exempt', textual recreations of the visual needed to fill the void created through their initial abnegation of the visual are both tolerated and sanctioned. The courts have freed themselves to construct the law of the visual as they go along, saturating the visuals with meanings as they choose, deploying interpretations and readings of images as it suits.

This juridical-aesthetic state of exception has another dimension to it. For Schmitt, the aesthetic in all of its variants 'negates and threatens' the political (Levi 2007, 38), making the 'aesthetic not simply a rival term to the political but its enemy' (Levi 2007, 40). In many respects, visuals and images are also law's enemy, being profoundly anarchic in contradistinction to law's serious enterprise. Paradoxically, this facilitates the conditions that allow the court as 'artistic everymen', knowing everything and nothing about images, to hide behind an aesthetic naïveté to impose readings of images that conform with sanctioned national narratives. And this is doubly-problematic for images and visuals that can be read

\footnotetext{
${ }^{1}$ Johansen v Art Gallery of NSW Trust [2006] NSWSC 577 [18]
} 
as Australian only through their 'vibe'. For if the courts cannot 'see' them in the first place because they do not meet the expectations of literally, truthfully, obvious Australian archetype, then the image and its legal fate sits in the aporia created by juridical-aesthetic state of exception.

\subsubsection{What do you see?}

One of the few identifiably Australian features of the defunct Australian band, Hunters \& Collectors, is that its members were (mostly) Australian and the place they created most of their music was Australia. Few other indicia point to the band's place in the world. Its name came from a track by the German band Can, but the band's cultural status meant it was a natural choice as a title of a scholarly cultural history of the people who developed ethnographic and archaeological collections in Australia (Griffiths 2006). ${ }^{2}$ Growing out of late 1970s Melbourne, the band blended an art house style intellectualism with a post-punk grinding, percussion and horn sound, ${ }^{3}$ a 'reggae-funk fusion with rock roots and a tinge of New York underground in the guitars' (Forster 2008). ${ }^{4}$ Their first single, 'Talking to a Stranger', released in 1982, began with a line repeated throughout: 'Souvent pour j'amuser [sic] les hommes d'équipage', an imperfect rendering of the opening line of Charles Baudelaire's poem, 'L'albatros', while the title referenced a pathbreaking 1966 BBC television drama series. ${ }^{6}$ Curiously, European ears heard the raw pulsating sound as that of indigenous Australians, which was not intended by the band (Seymour 2008, $215-218)^{7}$

Despite critical acclaim, the band changed course during the 1980s, and now answering to (though not wearing), the abbreviated moniker of 'Hunnas', the band reinvented themselves as exponents of a quintessential, mainstream, Australian-style 'pub rock'. ${ }^{8}$ Now archetypally Australian as captured

\footnotetext{
${ }^{2}$ Griffiths' book is entitled Hunters and Collectors: The Antiquarian Imagination in Australia. Griffiths notes: 'To European eyes, Australia had relic forms of nature and a primitive people. It was a land of living fossils, a continental museum where the past was made present in nature, a 'palaeontological penal colony' (Griffiths 2006, 9). One of the areas of law which will be explored in this chapter is Australia's Protection of Movable Cultural Heritage Act 1986 (Cth), which protects these kinds of cultural objects. Griffiths notes: 'To European eyes, Australia had relic forms of nature and a primitive people. It was a land of living fossils, a continental museum where the past was made present in nature, a 'palaeontological penal colony'. (Griffiths 2006, 9)

${ }^{3}$ To most Australian ears, this could not possibly be an Australian song in the literal sense, though it was embraced by an Australian art-punk sub-culture who adored this band and its raw sound and reliance on extraordinary visual images created by the filmmaker Richard Lowenstein in their early film clips

${ }^{4}$ Forster was a founding member of another iconic Australian band, The Go-Betweens, whose song 'Cattle and Cane' is a classic that drips with the torpor of a blindingly hot, humid Queensland summer

${ }^{5}$ The actual first line of the Baudelaire poem is 'Souvent, pour s'amuser, les hommes d'équipage'

${ }^{6}$ Janet Moat, 'Talking to a Stranger' (1966) British Film Institute

${ }^{7}$ Seymour refers to a Swedish press conference in 1988 where local journalists made this connection, which the band sought to disabuse

8 'Hunnas' is the phonetic rendering of the first part of the band's name. The ' $t$ ' consonant is often lost in the working class 'broad Australian' accent where it meets another softer consonant, so that 'hunter' sounds like 'hunna', 'winter' like 'winna'. Not all Australians have this accent, but the phonetic spelling of the first part of the name became a nickname for the band. The contraction of the name to its first word only is typical of Australian speech in general, where contractions will be used whenever they can - so 'sunglasses' become 'sunnies', 'journalists' become 'journos', 'hunters and collectors' become 'hunters' or 'hunnas'
} 
through its popularity, the songwriting of its lead singer, Mark Seymour, continued to be esoteric. It was into this mix that the band had a hit that seemed to capture an enduring image of Australia in the 1987 lament, Do You See What I See?, from which this chapter's title is taken. ${ }^{9}$ With its invocations of heat and summer, love and memories lost, existential and discordant, redolent of a blinding and harsh summer light, this song signifies a singular Australian experience. With a grinding bass line, and references to suburbs and cities, 'tea towels flying by', 'long drives north to the ocean', 'light shining ... hotter than the sun', this could only be Australia in summer. But the linear notes about the song published on a compilation album 16 years later confound this reading. ${ }^{10}$ Its inspiration is not Australian at all; instead the song comes from an experience in neighbouring New Zealand, a three hour flight from east coast Australia. The linear notes reference archetypically New Zealand images, including references to an Auckland suburb, a beach region near Auckland called Coromandel, the city of Dunedin, a hangi, an Aoteroroa tea-towel, a Steinlager shower, among other things. ${ }^{11}$ A song which could only be about an Australian experience has its provenance shattered, its origins confused. ${ }^{12}$

The information about the song's New Zealand origins confounds its status and character as an Australian song. A song like this, with an invisible invocation of place and identity, is emblematic of the porosity of text, language, and experience - there is nothing that obviously makes it Australian, except, perhaps, its vibe. ${ }^{13}$ It does not accord to 'typical' notions or images of Australia: koalas or kangaroos, Uluru, the Sydney Opera House or Bondi Beach. A decision by the Australian High Court in 1998, the year that Hunters \& Collectors broke up, decided that the phrase the 'Australian content of programs' meant television content typically 'Australian'. ${ }^{14}$ A song like Do You See What I See?, within the parameters of the test created by the court, would struggle to be treated as an Australian song, and would instead, at best, be characterised as a New Zealand song. ${ }^{15}$ If it ever became a legal question to be resolved, however, the song would 'count' as an Australian song, but not because of its content - its provenance, genesis, lyrics or sound - but solely because of barest of reference points: the nationality of its creators.

\footnotetext{
${ }^{9}$ The song has been confused with the gentle 1960s American Christmas song, Noël Regney and Gloria Shayne Baker, Do You Hear What I Hear?, which includes the phrase 'do you see what I see' throughout

${ }^{10}$ Natural Selection, Liberation Records 2003

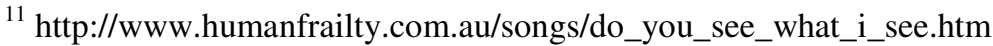

${ }^{12}$ New Zealand and Australia are near neighbours, fierce sporting rivals, share a common bond through the loss of its troops in World War One along with the ANZAC memorial, and are parties to a Closer Economic Relationship Treaty, but are not the same culturally, politically or socially. Ask a New Zealander to say 'six' and Australian ears hear 'sex' or 'sucks'; ask an Australian to say 'six', and New Zealand ears will hear 'seeeks'

${ }^{13}$ The idea that Australian creative outputs can only be truly Australian if they 'look' or 'sound' Australian is not confined to the courts. When an Australian music writer, Craig Mathieson, suggested in 2009 that there was such a thing as an 'Australian sound', the author of a letter to the editor in Sydney's major daily newspaper bristled, claiming that only lyrics about Australian culture, history or politics would qualify, or singers with certain accents, but there could certainly not be an Australian sound. The author of the letter approached the question of sound' as the courts do, by extracting out those things that are 'typical', and can be known with certainty (Conomy 2009)

${ }^{14}$ Project Blue Sky v Australian Broadcasting Authority (1998) 194 CLR 255

${ }^{15}$ The reading of Australian content by the High Court will be considered later in this chapter
} 
So this is the problem. Because the judicial eye is empiricist (Leiboff 2007, 2009), and relies on literal and 'commonsense' readings of the visual or other cultural texts (Hasenmueller 1989; Leiboff 1998), it can identify elements that are typically or archetypically Australian only because it draws on visual clues that conform to a pre-imposed vision of what should be 'there'. The method discards images and visuals unrecognisably Australian, easily comprehending clichéd images or visuals but failing to comprehend anything else (Mount 2006). Law can find identifiable ideas and elements - indicia certawhich it will trust as a vehicle capable of truth-telling. But these indicia certa are untrustworthy, capable only of knowing parts of an image or visual only, and the resulting image that discards what it cannot comprehend results is partial, distorted and incomplete. What is left is a misshapen, misapprehension of the image that is now used as the basis for legal decision-making in which the juridical-aesthetic state of exception can operate to achieve whatever legal outcome is desired in the case.

So Do You See What I See?'s national identity, in law, would be ascertained outside the song's frame, in the linear notes that will identify song's content as verifiably New Zealand images, thus shrinking the unverifiable Australian 'vibe' of the song from view. The content of the song is read absent its content, in effect, leaving a nonsensical reading behind. Because New Zealand origins aside, the sound and lyrics of this song speak with an Australian vernacular, were created out of the Australian experience, and are experienced as Australian by other Australians. This, for what it is worth, is what I see. What, then, did you see?

\section{2 'THE VIBE'}

\subsubsection{Hooked on a feeling - the vibe}

'Vibe' is a word of the late $20^{\text {th }}$ century, its origins found in the world of rock and pop music. Included in its uses in the Oxford English Dictionary is one of its verb forms: 'To transmit or express (a feeling, attitude, etc.) to others in the form of intuitive signals or 'vibes". In the Australian Macquarie Dictionary, 'vibe' is defined as a colloquial term meaning 'a dominant quality, mood, or atmosphere'. 'Vibe', then, captures the notion of a communication of a 'feel' without recourse to the sensational or verifiable. For this reason, it lacks the quality that law prizes, namely, an ability of things to be determined with certainty. Law must, because of its empiricist methods, discard 'the vibe' from the mix in reading visuals and images because its truth cannot be secured with any empiricist precision; the vibe cannot be determined with certainly, so it simply does not exist.

However, 'the vibe' has the potential to function as a vivid heuristic device through its denotative capacities, charmingly illustrated in a moment from the iconic 1997 Australian comedy film The Castle (Beckingham 2000), where 'the vibe' was used by a barely competent lawyer to explain a gap in the text of the Australian Constitution when trying to argue why Australians have an unusual relationship to home ownership: 'There is no one section [of the Constitution], it's just the vibe of the thing ... In summing up, it's the Constitution, it's Mabo, it's justice, it's law, it's the vibe and -- No, that's it. It's the 
vibe!'. This marvellous passage (which was unsurprisingly unconvincing as an argument before the fictional court), sought to capture a sense of the relationship Australians have with home ownership that could not be described to the court in any 'real' terms, nor which could be defined with precision through the literal texts of the law (MacNeil 2007, 116 -131). Yet the concept of home ownership, as an expression of property rights, is something embedded in the interstices of law through its jurisprudence, which the lawyer attempted to capture through 'the vibe'. But 'the vibe', as expressed in this passage from the film, has created its own denotation, 'a vibe' of its own, a shared meaning about the Australian experience. 'The vibe', in the Australian context at least, means this vibe, referenced in this scene. The word still captures its dictionary meanings and it leaves an image in the mind of this moment from this film. Despite this, ironically almost, the vibe is unconvincing for law. But I will suggest 'the vibe', as expressed through the schema of a Panofskian iconology, can be the tool through which that indefinable 'something' can be 'seen' by the judicial eye, and perhaps enable it to see what $I$ see.

\subsubsection{A Panofskian semiotic of the visual: a methodology of the vibe}

As I have suggested here, law has no effective language, no logic, through which it can read images or visuals in any way other than its conventional practices will allow (Goodrich 1996, 52; Darian-Smith 1999, 56 - 57). In order to find another way to comprehend them, I propose that it draw on insights provided by art history, a discipline skilled at reading visuals and images through processes of signification (Bal and Bryson 1991, 188 - 191; Potts 2003). Indeed, semiotics are used to enable art historians to explore 'the polysemy of meaning; the problematics of authorship, context, and reception $\ldots$ the claims to truth of interpretation' (Bal and Bryson 1991, 174). Yet as Pettersson implies, the readings of images are always open to interpretation, especially in poststructural readings of images (Pettersson 2001, 65). So in a sense, the open meanings that are of value to art history become, within law's empiricist logic, nothing other than the reading of signs as simply another form of the ideational or elemental. Plus ça change.

So rather than draw on a semiotics of the visual in its broadest sense, I propose the use of a more confined semiotic: Erwin Panofsky's iconology (Hasenmueller 1978). Developed in the 1930s, iconology is an interpretative method of reading images which aims to establish their meanings (Timmerman 2001). Interdisciplinary and contextual, the technique draws on a range of disciplines in order to 'find' objectively determinable meanings. Panofsky's work has thus been criticised because of its desire for certainty and truth, and has been dismissed as an idiosyncratic, culturally conditioned, prewar precursor to a more explicitly developed semiotic and its desire for objective, definable readings of the texts of visuals and images (Bann 2003; Preziosi 2009, 218 -219). But while an open sign system is of fundamental value to art historians (Bal and Bryson 1991, 186-187), lawyers merely need to be given tools to assist them read images beyond the literal and formal, and it is precisely for the reasons Panofsky is criticised by art historians that I see a value in the use of this hermeneutic in the legal context through its creation of a 'synthetic intuition' that would establish a method to avoid the aporetic 
problems of the juridical-aesthetic state of exception that would dismiss 'the vibe' and replace its lack of form with a reconstructed image of the visual or the image for the purposes of law's empire.

Firstly, the technique shows that empiricist and literal readings of images and visuals are misleading and partial, and secondly, its schema offers a certainty and methodological rigour so that 'the vibe' moves from being a mere feeling to something which can be ascertained through a method, providing a sense of certainty whilst curtailing unbounded interpretations. Grounded in a tripartite schema of preiconography (observation), iconography (analysis) and iconology (meaning), the pre-iconographic description and iconographical levels function as correctives or controls to temper subjective interpretation pregnant within the iconological, and thus open to the charge that the reading of the image will be irrational because of the interpretive tendencies of the viewer (Panofksy 1955, 38). In other words, a Panofskian iconology provides a technique to give the judicial everyman a device to construe visuals and images, and in doing so allows the courts to see visuals that do not meet the expectations of literally, truthfully, obvious Australian archetype.

\subsubsection{Speaking to law: meanings and the place of iconology}

To the legal mind, superficially at least, the phases of the Panofskian iconological schema may seem familiar. A similar technique is found in Ronald Dworkin's interpretative schema used to find the law in hard cases. Law, as Dworkin reminds us, is not found through literal readings of statutes or cases, but exists as a complex set of rules and principles located within the interstices of its own texts. Dworkin's method aims to find those principles, its fundamental meanings, through a set of methods that speak to law's conservative practices and desire for certainty. My purpose here is not to praise Dworkin, or to sanction his methods, which are problematic and impose their own limitations, but to explore how the legal imaginary can work within interpretative schemas and structures of the kind Panofsky constructed.

Like Panofsky, Dworkin uses a three-stage process: a pre-interpretive stage where a rule is found from the vast panoply of law, followed by an interpretative stage which seeks to find out what the rule actually means, and a final post-interpretive stage that uses the interpretation of the rule as the guide to ascertain the correct law to be used in the hard case under consideration (Dworkin 1986). There are differences of course, not least Dworkin's internalised hermeneutic differs from Panofsky's interdisciplinary and contextual hermeneutic, but both seek to interpret the correct meaning of either the law or of the image in question.

So if law and its practitioners are more than capable of reading texts using interpretative devices, they should be open to be convinced that the reading of images as literal and descriptive is as problematic as reading law only through a literal and descriptive lens (Leiboff and Thomas 2009). Panofsky shows that visuals or images are much more than their literal or descriptive elements, thus showing in full light the problems that arise when the courts rely on the juridical-aesthetic state of exception. 
So what does the method propose? Panofsky articulated his conception of the iconological through a series of different works (Panofsky 1955, $40-41$ ), but for this purposes of this chapter, I rely on his celebrated synoptical table of art historical interpretations. The table sets up four delineators which are used in the process of engaging with the image or visual. These delineators are structural and formal in nature, and seek to identify (1) the object of interpretation (what is being read or seen), (2) the act of interpretation (whether it is pre-iconographic etc), (3) the equipment needed for interpretation (visual literacy), tempered by (4) a corrective principle of interpretation (evidence) (Panofsky 1972, 5 - 9). As will become apparent, the phases exist both independently and interdependently in their development of the process of interpretation of the visual or image under consideration.

The first phase, the pre-iconographic, concerns the reading of 'primary or natural subject matter' of the image or visual, which takes either a factual or expressive form, a process roughly similar to Dworkin's pre-interpretive stage. This matter, reminiscent of the literal and empiricist modes of viewing images used by the courts, is something capable of description by a viewer. Panofsky identified that the equipment needed here is simply practical experience or a familiarity with objects and events. While it may seem that 'any reading is good enough', this is tempered by the corrective principle of interpretation - here, the history of style, or an insight into the manner in which, under varying historical conditions, objects and events were expressed by forms. This phase demonstrates that a bare reading of an image relying on certainties of the empiricist methods favoured by law are likely to be erroneous, as they fail to draw on correctives of the kind identified here.

The second phase - the iconographic - is interpretative, and has some similarities with Dworkin's second stage. The object of interpretation of the iconographic is secondary or conventional subject matter, constituting the world of images, stories and allegories. The equipment needed for interpretation is knowledge of literary sources, or familiarity with specific themes and concepts. The corrective principle of interpretation is the history of types, that is, insight into the manner in which, under varying historical conditions specific themes or concepts were expressed by objects and events. These factors will be read into a visual or image, if the viewer has been introduced to these textual interpretants.

The third phase, in some ways reminiscent of Dworkin's third stage, is the iconological, which has as its object of interpretation the intrinsic meaning or content of an image or visual. The equipment needed for interpretation is synthetic intuition, a familiarity with the essential tendencies of the human mind, conditioned by personal psychology and Weltanschauung, which roughly translates to mean a fundamental cognitive orientation of an individual or society, the lens through which an individual interprets the world and interacts with it. In short, the ability to understand the meaning of a work requires an understanding of the conditions or circumstances involved in its creation. This, then, is an objectively grounded interpretation, tempered moreover by the corrective principle of interpretation for this category, namely an understanding of the deep structures of the social condition underpinning the creation of the visual or image. 
In order to ascertain the iconological, Panofsky requires the viewer to rely on the history of cultural symptoms or "symbols" in general, or an insight into the manner in which, under varying historical conditions, essential tendencies of the human mind were expressed by specific themes. So the visual or image is 'a manifestation of fundamental principles in a culture, a period, or a philosophical attitude. Following Cassirer, Panofsky regards artistic motifs, images, and allegories as 'symbolic forms', as 'symbolic equivalents of reality constructed by the intellect' (Timmerman 2001). In effect, the iconological phase seeks to find 'the vibe' by drawing on what is known about image or visual through symbols that represent the character of its creation. In short, to read an image or visual absent the iconological or the 'vibe' is to read a partial and incomplete account of the image, as is the case in images foreclosed through the readings imposed by courts of a partial, literal and empiricist reading that characterises the juridical-aesthetic state of exception.

\subsubsection{Hunnas, the vibe, and Panofsky's method}

In order to see the difference that exists between the two methods - the legal empiricist approach and Panofsky iconography - what happens when a song like Do You See What I See? is read against Panofsky's schema? Panofsky owned that each of his phases was interlinked and intertwined, and it is apparent when reading the song that it would be impossible to conceive of the phases as clear and distinct; but that each contributes to build a reading of the visual or sound, in this case, that results in confirming the 'vibe' of the song as Australian. It is as though the 'synthetic intuition' he proposed, when employed to read a visual conforms with intuition more generally. In this case, the vibe starts to become apparent through reading the key images in the song: of summer, sun, the light, the beach and a grinding and harsh sound, using knowledge of the time and place and oeuvre of Australian music in the 1980s. This iconographic method gives us a technique, formal though it is, to read the song as a whole, a sum of its parts both visible and invisible, as each phase is revealed.

In terms of the pre-iconographic phase, the primary or natural subject matter of the images created by song is that of a summer road trip to the ocean. Made concrete through images of tea towels flying by, light hotter than the sun; its sound is harsh and grinding, not lyrical and sweet, suggesting a harsh Australian summer experience. The pre-iconographic must include knowledge about the song's New Zealand connections and images. The iconographic, or the secondary or conventional subject matter constituting the world of images, stories and allegories, makes meaning out the images of a blinding Australian summer, and knowledge that the description of such an intense light could only exist in Australia. New Zealand is not a hot country; its light is diffuse and gentle, and the music it produces for the most part, is lyrical and gentle. The sounds of 1980s Australian pub rock are evident in the harsh and discordant sounds; Mark Seymour's lyrics sit with the esoteric music of Nick Cave, The GoBetweens, and The Cruel Sea, places music within both oeuvres. Iconographically, this could only be an Australian song. Finally, the iconology of the song, its meaning, is found in its harsh and discordant sounds and plaintive, angry lyric; a motif not of kangaroos and koalas, but of a middle-class angst that 
found its expression in pub rock laments. This is a very different Australia from one found in the picture postcards and newsreels. This, then, is the song's 'vibe'.

Yet there is always the chance that another person will read the song differently (Hasenmueller 1981). For all of its claims to finding an essential position, despite the objective correctives contained within the method, competing readings can still be made. And this is a complication; the chance that competing readings of the same visual or image will mean the courts will have to make decisions based, in existing terms, on mere opinion. Yet this is what courts always do; they are presented with different readings of the law, and accounts of events from both 'sides', and they make decisions one way or another. The vibe, in the terms proposed here, establishes some kind of common ground in order to read the text of an image or visual - and if a choice needs to be made between competing readings, then the court will need to make a decision one way or the other. But first and foremost 'the vibe' - the adoption of the Panofskian schema - is designed to give voice to the meanings excluded from the reading of images and visuals by the courts. In the remainder of this chapter, I will consider what would happen if the court's reading of the images and visuals in question are tested against Panofsky's schema.

\subsection{A REVERSE ICONOGRAPHY: THE PROJECT BLUE SKY CASE}

\subsubsection{An Australian Television industry}

This word-picture contained in Do You See What I See? has a certain ironic, real-life legal counterpart in a case that tells us that though the song would be treated as Australian because of the origins of its creators, the song itself would not be Australian. In 1998 Australia's ultimate court, the Australian High Court, decided that New Zealand television content had to count as 'Australian content' on television (Leiboff 1998). The decision was grounded in a Closer Economic Relationship Treaty between the two countries, which had been breached by rules establishing a transmission quota designed to ensure that Australian content would be shown on television, thus favouring the provision of services by Australians over New Zealanders. The rules breached the treaty because they tested the character of the content through a 'creative control test' designed to embed an Australian perspective through the input of Australian creators. The High Court decided that 'creative control' could not be squared with the meaning of 'the Australian content of programs', though the rules could count content created by Australians - for historical reasons. New Zealand content thus had to be counted in the transmission quota, and Australian prime time television now shows New Zealand programs about motorway patrols and ambulance services, displacing Australian cultural material.

Whilst grounded in the primacy of a trade treaty, the decision could not have been made without an interpretation of what was meant by Australian content. Grounded in the factual, objective and elemental, the High Court's decision was based in their own commonsense view of the status of images and visuals, and through the indicia certa of those things recognisably Australian, a reverse iconography which 'corrected' an aberrant 'creative control' test to one grounded in literal, corporeal 
content. I will reach into the decision, and the engaging set of encounters between the bench and counsel, where the court's idea of Australianness is open for all to see.

\subsubsection{Images, content, or origins: the making of Australian content}

Australia encourages the creation and production of its own 'audio-visual content' in order to support a production sector and provide audiences with their 'own' content. Since television began in the late 1950s in Australia, broadcasters have been required to broadcast certain amounts of content created by Australians. ${ }^{16}$ In the early 1990s a new Australian content standard, Television Program Standard 14 ('TPS 14'), was promulgated, but because of changes in the law, ${ }^{17}$ it was speedily replaced in 1996 by the Australian Content Standard, which required, as the contemporaneous Explanatory Notes to the Australian Content Standard indicated 'commercial television services to be predominantly Australian by requiring a minimum amount of Australian programming and minimum amounts of first release drama, documentary, children's drama and other children's programs'. It counted programs created by Australian nationals or permanent residents as Australian content, and if key positions were filled by Australians - producers, directors and writers, and actors or on-screen presenters - content could be made anywhere, so long as it was 'under Australian creative control'.

Recognising the difficulties that may be found in the court's embracing 'the vibe', the test sought to construct an Australian culture through the nationality of the creators of the work, rather than trying to rely upon the indicia certa of Australianness that would deny an Australia identity to creative outputs like those of Hunters \& Collectors. Yet in the Project Blue Sky case, the High Court could not accommodate, could not understand, that a creativity without literal, clichéd, or stereotypical elements was capable of constituting Australian content. These readings can be found throughout the judgments, which I will come to shortly, but there is another extraordinary source that reveals quite what the court was struggling with in the exchanges between members of the Bench and counsel in the transcripts of the hearings in the case. I will let these encounters speak for themselves.

The first exchange occurred in the very short special leave hearing between counsel for the regulator, Mr Gyles QC and one of the members of the bench which resulted in the High Court deciding to hear the case in full:

\footnotetext{
${ }^{16}$ Section 114 of the Broadcasting Act 1942 (Cth) required the use of the services of Australians as far as possible in the production and presentation of programs, subsequently mandated in the mid 1060s as a quantitative requirement that $45 \%$ of commercial television content be Australian content. During the 1970s and 1980s, a more qualitative approach was taken, requiring amounts of Australian drama, variety programs, and information programming, and so on. A transmission percentage or points system operated

${ }^{17}$ The Broadcasting Act 1942 (Cth) was repealed in 1992 and replaced with the Broadcasting Services Act 1992 (Cth). Old s 114 was replaced with s 122 (2) (b), which required the regulator to make standards for commercial television, 'in relation to the Australian content of programs'. It also had to conform to s 160 (d), requiring it to act in a manner consistent with Australia's obligations under any convention to which Australia was a party or any agreement between Australia and a foreign country
} 
KIRBY J: Is it possible to make the whole thing work by saying, "You have got certain Australian content obligations but because of 160, for "Australia" read "Australia and New Zealand".

MR GYLES: That, your Honour, is the argument which my learned friend has eschewed at all times.

KIRBY J: Why? New Zealand is very close. It almost did join us. It is still in the covering clauses [of the Australian Constitution].

MR GYLES: Yes, and it is said, except in matters of rugby, they are quite close, your Honour. It is, in our submission, not logical to suggest that you can have Australian content fixed by a standard which fixes a particular level of Australian content but says you can satisfy that by New Zealand content. We submit that that is logically and legally nonsensical. ${ }^{18}$

Rugby matches between the two countries were of real significance in this case. Rugby, or Rugby Union, is a code of football that is, generally speaking, popular with members of Australia's legal profession. ${ }^{19}$ Australian content, as conceived by the regulator is much broader, much more comprehensive that a football match between two countries, comprising rules about news, current affairs, drama, comedy, documentaries, and much more. But this theme was to continue in the full hearing, where the problem of characterising the 'content' of rugby matches was central to considering the meaning of the 'Australian content of programs'. It is found again in this second exchange which occurred in argument before the court, this time between a vexed Chief Justice and counsel for the New Zealand production company which had commenced action against the regulator:

BRENNAN CJ: Mr Ellicott, I am having a difficulty understanding the Standards definition of Australian programmes. This is clause 7 of the Standards. If the Bledisloe Cup is played in Melbourne, is that an Australian programme $?^{20}$ If it was played in Auckland, is it not? ${ }^{21}$

MR ELLICOTT: I think there is an exception in relation to that, your Honour. It is still an Australian programme ... [clause 7] would take the Bledisloe Cup in Auckland into account by Australian film crews.

BRENNAN CJ: Provided the earlier paragraphs of that subclause are satisfied as well.

\footnotetext{
${ }^{18}$ Project Blue Sky Inc and ORS v Australian Broadcasting Authority S219/1996 [1997] HCATrans 135 (11 April 1997) http://www.austlii.edu.au/cgi-bin/sinodisp/au/other/HCATrans/1997/135.html

${ }^{19}$ A little explanation is needed however. Two of Australia's states are 'rugby' states - Queensland and New South Wales. It is noted that the Chief Justice was from Queensland, while Mr Ellicott QC was from Victoria, where Australian Rules football (AFL) holds sway, and its inhabitants on the whole have a lesser familiarity with the nuances of rugby

${ }^{20}$ The annual series of rugby matches between Australia and New Zealand- some matches are played in each country

${ }^{21}$ New Zealand's largest city
} 
MR ELLICOTT: Yes, it is oriented towards Australian producers and actors and, I do not think finance - - -

BRENNAN CJ: Then the Bledisloe Cup in Auckland with a cast of thousands would be mainly New Zealanders, would they not?

MR ELLICOTT: They certainly would, your Honour. It is much better when you are watching the AFL grand final, your Honour [sic].

BRENNAN CJ: It seems that this definition though is really looking at two quite disparate matters. One is the cultural content of a programme and the second is its origins ... so that one says, "Well here is an Australian content. It was made by Jane Campion in New Zealand, ${ }^{22}$ but it is an Australian story about the outback". Well then, one can see very clearly that that can be an Australian programme [emphasis added].

MR ELLICOTT: What is important first of all, in answering what your Honour has put to me, is to look at what [the regulator has] actually done ...: 'it is produced under the creative control of Australians who ensure an Australian perspective'. ${ }^{23}$

The problem of the rugby match continues in the final encounter, again between Mr Gyles QC and Kirby J. Mr Gyles QC tries to continue the rugby analogy:

MR GYLES: Your Honours, whilst you have the content Standard open at page 17, I could work the Chief Justice through the Bledisloe Cup - it might be interesting to see how that works its way through.

KIRBY J: Would you explain to me what that Cup is all about?

MR GYLES: Your Honour, it is about a game called Rugby between Australians and New Zealanders which is from time to time played in New Zealand. Let us consider a game played at Wellington. It is 7(4). The producer of the programme must be Australian under (a) and the director must be an Australian under (b), (c) "not less than $50 \% \ldots . .$. of the on-screen presenters......are Australians. So if one has Simon Poidevin and Chris Handy and Gordon Bray and nobody else, ${ }^{24}$ you comply with that ...

KIRBY J: It does not qualify as a drama programme?

\footnotetext{
${ }^{22}$ A New Zealand film director who also works in Australia

${ }^{23}$ Project Blue Sky Inc and ORS v Australian Broadcasting Authority S41/1997 [1997] HCATrans 302 (29 September 1997) http://www.austlii.edu.au/cgi-bin/sinodisp/au/other/HCATrans/1997/302.html

${ }^{24}$ The former are Australian representative players who at the time were commentators and the latter is a renowned Australian rugby commentator
} 
MR GYLES: No; not under the definition, your Honour, although it does, from time to time, in the living room.

The rugby match became the ideal vehicle through which the court ventilated its confusion about the meaning of Australian content - or was it New Zealand content. It reveals the extent to which it focussed on the physical and tangible - players, supporters, commentators, and locations - and not the feel or the vibe of the game and its atmosphere. But it was the Chief Justice's mystification about 'the cultural content of a programme' on the one hand and its 'origins' on the other and the problem of 'seeing' content created in New Zealand as Australian that is most telling. There is a clear sense of what makes something Australian - a film about the outback, for instance, even in the hands of a New Zealand director - would qualify as Australian because it is visibly, definably, verifiably Australian. But the music of a band like Hunters \& Collectors would struggle.

\subsubsection{The Australian content of programs}

The narrow conception of Australian content, in the eyes of the court, found full expression in the judgment itself where it relied upon the juridical-aesthetic state of exception to 'correct' the misconceived polysemous 'vibe' that the broadcasting regulator had included in its Australian content rules, and reconstitute a 'true' conception of what constituted Australian content in its place (though the court conceded that vibe based rules could remain but only because they had been relied upon historically).

Two judgments were delivered, in much the same terms, one by the Chief Justice, and other by the remainder of the court as a majority, the latter deciding that the Australian content of programs:

is a flexible expression that includes, inter alia, matter that reflects Australian identity, character and culture. A program will contain Australian content if it shows aspects of life in Australia or the life, work, art, leisure or sporting activities of Australians or if its scenes are or appear to be set in Australia or if it focuses on social, economic or political issues concerning Australia or Australians. ${ }^{25}$

Yet there is nothing flexible about this interpretation. It is a literal pre-iconographic reading of images identifiable because they 'look' Australian. This reading ignored the possibility that the iconological, the vibe would also constitute Australian content. The majority appeared to recognise, at a practical level, that such an open test would allow any content created about Australia, wherever it was created would count as Australian content, and they grudgingly accepted that:

Given the history of the concept of Australian content as demonstrated by the provisions of TPS 14, a program must also be taken to contain Australian content

\footnotetext{
${ }^{25}$ Project Blue Sky v Australian Broadcasting Authority (1998) 194 CLR 255 [88]
} 
if the participants, creators or producers of a program are Australian. Nothing in the notion of the Australian content of programs requires ... that such programs should be under Australian creative control. ${ }^{26}$ (Emphasis added)

This abrupt dismissal of the creative control test denies the possibility that 'the vibe' or non-literal Australian content may 'count' under the rules. But the Chief Justice would not have accepted even the limited concession of the history of TPS 14; for him, Australian content is only to be found in its literal presentation: "The "content" of a "program" is what a program contains ... "Australian" is the adjective describing the matter contained in the program; but the matter contained in a program is not its provenance. ${ }^{27}$ Unlike the majority, he refused to allow the creators a stake: 'There is neither historical nor textual foundation for the proposition that the term can be used to classify programs by reference to their provenance'. ${ }^{28}$ But the Chief Justice went on to engage in an exegesis of elemental and the ideational in determining what was meant by content, which he saw as the expression of ideas, retrofitted to a particular iconography of Australia:

The content of a program for broadcast may be difficult to define in a statute, for it has to do with the communication of sights and sounds that convey ideas and the classification of an idea as "Australian" is a rather elusive concept. But that is not to deny the reality of Australian ideas; they are identifiable by reference to the sights and sounds that depict or evoke a particular connection with Australia, its land, sea and sky, its people, its fauna and its flora. They include our national or regional symbols, our topography and environment, our history and culture, the achievements and failures of our people, our relations with other nations, peoples and cultures and the contemporary issues of particular relevance or interest to Australians. ${ }^{29}$

But there is something in this characterisation of Australian content by the Chief Justice, through the sights and sounds included in his list, that is reminiscent of Cassirer and Panofsky's 'symbolic forms', an attempt by him to capture the sense in which forms function as symbolic equivalents of reality constructed by the intellect. Following from his vexed response to the characterisation of the rugby match as both placeless and placed in one, the Chief Justice ultimately set out a listing of Australian types as archetypes. Rather than embedding content, this is mere empty symbolism, through the denial of the role of the creator in embedding their experiences into the text of that content. This is a literal pre-iconography, through which stories and events that do not function within a preconceived notion of Australianness cannot be given voice. The iconological is thus dismissed through the attempt to capture a literal image, but the image without meaning cannot carry the iconological.

\footnotetext{
${ }^{26}$ Project Blue Sky v Australian Broadcasting Authority (1998) 194 CLR 255 [88]

${ }^{27}$ Project Blue Sky v Australian Broadcasting Authority (1998) 194 CLR 255 [22]

${ }^{28}$ Project Blue Sky v Australian Broadcasting Authority (1998) 194 CLR 255 [26]

${ }^{29}$ Project Blue Sky v Australian Broadcasting Authority (1998) 194 CLR 255 [22]
} 


\subsubsection{Retrieving the iconological in the Australian content of programs}

The High Court's conception of a circumscribed Australian content has excluded non-literal forms of Australian content from law's conception of what constitutes Australian; ironically, the test created by the court permits content created by non-Australians to count as Australian, if they display images of Australia. This is the juridical-aesthetic state of exception rendered as a state of confusion, as literal text as misconceived text. So, would the use of Panofsky's schema have enabled the High Court to comprehend a vibe-based creative control test of the kind constructed by the broadcasting regulator that would find a space for creative outputs that are not literally or stereotypically Australian?

To find this out, I will also use the trope of the rugby match, and the polysemy of the literal reading of the visual references that so vexed the Chief Justice - would the location matter, would the preponderance of New Zealand spectators matter, and so forth? The pre-iconographic shows us that the teams from each country, unequal numbers of supporters in team colours, commentators, camera angles, and so on means that literally speaking, the literal reading of the rugby match results in a nonsense interpretation of the event. It is neither Australian nor New Zealand but a set of bare elements that are devoid of meaning. It takes more to create an image or visual expression, and this is found in taking the bare and literal pre-iconographic elements to shape them into more than the elements that constitute the pre-iconographic. This may be found in the super-added elements that go on to create a television program, and that shape its content to create a vibe, which may include the views expressed by, and the call made by commentators, the camera angles chosen by the director and so on. To watch this rugby match in New Zealand on New Zealand television is a very different experience to watching it in Australia on Australian television. Even if both use exactly the same feed, the commentary differs, the replays differ, and the directorial choices of crowd images differ. The creation is not the same as the bare material, the indicia certa which can be vouchsafed through one team which wears gold and one which wears black, and a location either in Australia or New Zealand.

But there is more. These rugby matches are iconological in their own term, which informs the iconographic, and is easily read through the history of the matches and the epic and enduring struggle for supremacy between the two countries, perhaps exemplified by the New Zealand Haka grounded in Maori tradition that is used as a challenge to Australia. And, unfortunately for Australian fans, Australia routinely loses to New Zealand. Iconologically, the Weltanschauung will, as Mr Gyles QC recognised, constitute the drama that occurs in the living room when watching the game, ${ }^{30}$ and that is the vibe that makes the content Australian, even though the original text from which that vibe is created is identical.

The decision of the High Court to misread the text of the Bledisloe Cup is an exemplar of the juridicalaesthetic state of exception. Here it resulted in a legal interpretation that has created a precedent that

\footnotetext{
${ }^{30}$ Having been in New Zealand once during the Cup and having watched the broadcast of the match, I know just how different the vibe was - the images emphasised, the accent and demeanour of the commentators, the proliferation of black (the New Zealand team is the All Blacks)
} 
is perverse in its practical consequences, because abjured a complete rendering of the text of a transTasman football match by focussing on the pre-iconographic at the expense of the iconological.

\subsection{MAKING THE IMAGE FIT THE LEGEND}

\subsubsection{Iconology and Australia's Movable Cultural Heritage Law}

Australia's Protection of Movable Cultural Heritage Act 1986 (Cth) protects its culturally significant objects, or movable cultural heritage, by retaining them in Australia using the device of refusing an export permit for an object. ${ }^{31}$ Deciding which objects are to be protected occurs in a number of stages, and includes the searching of a taxonomic listing of objects, after which a series of tests are used to determine the relative cultural significance of the object in question. Decisions to refuse exports are routinely reviewed, in order to have the object's status overturned, and through these reviews, we find what the judicial eye sees when looking at culturally significant objects. ${ }^{32}$

\subsubsection{Misreading iconologies, misreading legislation}

Law sees objects in much the same way it sees other images and visuals: as elemental, ideational, and describable in physical terms only. The problem for Australia's legal decision-makers is how to construe the cultural significance of an object if its meaning is determined only through its describable and quantifiable physical characteristics. In the leading decision determining what makes an object culturally significant, the relevant administrative tribunal was faced with conundrum involving a physically insignificant metal object was considered for cultural heritage protection. The metal object in question was a Victoria Cross ('VC') medal, the rarest and highest award in British and Australian military honours. The particular medal had been awarded to an Australian for bravery in World War One, ${ }^{33}$ but the tribunal could see nothing in the legislation that would let it protect it because it was not an Australian but a British Imperial medal minted in England using gunmetal from Crimean War canon.

This disjuncture between object and its cultural value and significance is exemplary of the interpretive practices undertaken in the juridical-aesthetic state of exception. 'Seeing', in this situation, was not believing until the tribunal creatively construed (or perhaps invented) a way to protect the medal for the nation, which it did by conceptually detaching the physical object from its political and social significances for Australia through narrative:

\footnotetext{
${ }^{31}$ Supplemented by the Protection of Movable Cultural Heritage Regulations 1987

Australia is a party to the Convention on the Means of Prohibiting and Preventing the Illicit Import, Export and Transfer of Ownership of Cultural Property 17 November 1970, Paris, and this legislative schema has been created in order to meet the requirements of this Convention

${ }^{32}$ Reviews are carried out on the facts, by judges, other lawyers and sometimes laypeople with particular expertise, who sit on the administrative tribunal responsible for reviewing government decisions

${ }^{33}$ Re Truswell and Minister for Communications and the Arts (1996) 42 ALD 275
} 
Certainly, it is the power of emotion which endows an otherwise unexceptional piece of gunmetal with the heroic status a VC possesses. But it is the power of emotion which is responsible for idealism, loyalty, patriotism, and so many other attributes to which we, as individuals and as a community, aspire. Similarly it is the power of emotion, as well as reason, which makes us respect our history and learn from its lessons. ${ }^{34}$

The tribunal, much like the High Court in the Australian content case, had a keen sense of Australianness in mind when making its decision. But this time, the tribunal turned to iconology writ large in order to read the object in a way that corresponded a sanctioned national narrative and identity. But this was a reading that had come about because it misread the object vis a vis the legislation. It had to play with the law to help the object conform to its iconological status as an emblem of the ANZAC spirit and personal bravery. In doing so, the tribunal drew on the bifurcation in the law relating to art objects, especially concerning their authenticity, between the description of the object on the one hand (as fact), and questions about it qualities or attributes on the other (as opinion) (Leiboff 2001). But if it had read the object using a Panofskian schema, it would have seen that the legislation actually protected objects because of their meaning and vibe; the objects in terms of describable physical characteristics were not meant to be distinct but integral to its cultural significance.

\subsubsection{A piece of moulded gunmetal decorated with a ribbon}

Section 7 (1) of the Protection of Movable Cultural Heritage Act establishes what is conceived of as the 'movable cultural heritage of Australia' through the listing of certain types of objects which are of 'importance to Australia'. It sets out the reasons why certain objects are important to Australia in order to establish a National Cultural Heritage Control List, ${ }^{35}$ which is to be made up of 'objects that are of importance to Australia, or to a particular part of Australia, for ethnological, archaeological, historical, literary, artistic, scientific or technological reasons'. ${ }^{36}$ But this enumeration and description of important

\footnotetext{
${ }^{34}$ Re Truswell and Minister for Communications and the Arts (1996) 42 ALD 275, 296

${ }^{35}$ Protection of Movable Cultural Heritage Act 1986 (Cth) s 8; s 7 (1) lists categories of objects:

(a) objects recovered from:

(i) the soil or inland waters of Australia;

(ii) the coastal sea of Australia or the waters above the continental shelf of Australia; or

(iii) the seabed or subsoil beneath the sea or waters referred to in subparagraph (ii); ${ }^{35}$

(b) objects relating to members of the Aboriginal race of Australia and descendants of the indigenous inhabitants of the Torres Strait Islands;

(c) objects of ethnographic art or ethnography;

(d) military objects;

(e) objects of decorative art;

(f) objects of fine art;

(g) objects of scientific or technological interest;

(h) books, records, documents or photographs, graphic, film or television material or sound recordings;

(j) any other prescribed categories (there is no (i)

${ }^{36}$ Protection of Movable Cultural Heritage Act 1986 (Cth) s 7 (1)
} 
objects is also used to guide the reading of an object's cultural significance under the key decisionmaking provision in the Act, $s 10$ (6). ${ }^{37}$ Section 10 (6) (a) requires that the decision maker have regard, among other things, to the reasons referred in $s 7(1)$ that are relevant to the object to which the application relates, and $s 10$ (6) (b) provides that it has to refuse an export permit if it is satisfied that the object is of such importance to Australia, or a part of Australia, for the reasons in $s 7$ (1), that its loss to Australia would significantly diminish the cultural heritage of Australia. These tests are replete with signification, and are built out of a Panofskian model, from the pre-iconographic descriptives of objects and the reasons for their significance, to a series of indicia of value and significance through which the iconographic is determined, before the final determination of the iconological in s 10 (6) (b).

But in this case, the tribunal misread this structure, and treated the pre-iconographic in an entirely different sphere of analysis from the iconological. It recognised that the value of each Victoria Cross 'entirely transcends its physical manifestation', ${ }^{38}$ but that on the basis only of its physical characteristics ... there would be no question of withholding an export permit'. ${ }^{39}$ Instead, to protect the iconological, it bypassed the object, by creating a different vehicle through which the iconological would be recognised: a separate and distinct 'intangible'. ${ }^{40}$ Ignoring what was already contained in the legislation, because it could see nothing there that would allow it to protect a physically valueless object, 'a piece of moulded gunmetal decorated with a ribbon', ${ }^{41}$ it misread both object and legislation (Leiboff 2007).

For the tribunal, an object could only have cultural value if it was materially and physically valuable. It could not see value beneath the skin, beneath the veneer of its materiality and corporeality. In its eyes, the medal was an insignificant object made up of gunmetal and a ribbon. Its eye misread the Victoria Cross as having no significance because of its material composition, and from there it misread what 'movable cultural heritage' sought to comprehend - that it incorporated within it a value other than its material form. So the tribunal dismissed the phrase, the 'movable cultural heritage' as being merely descriptive of a physical object. It then had to try to explain why a physically insignificant object could be important, which it did by looking outside this statute in order to determine what was meant by 'cultural heritage' generally. Deciding that it included customs, outlook, religion, folk-lore, music or

${ }^{37}$ The Protection of Movable Cultural Heritage Bill 1985 (Cth) Explanatory Memorandum, Clause 8: National Cultural Heritage Control List indicated that

The List will be based on the categories given in clause 7 and will set out for each category those criteria which will be used to determine whether or not an object falling within that category may be judged to be of such importance that its loss would significantly diminish the cultural heritage of Australia.

The Protection of Movable Cultural Heritage Bill 1985 (Cth) Explanatory Memorandum, Clause 10: Grant of Permits provided that:

When considering the application, the expert examiner, the Committee and the Minister shall all take into account, amongst other things, the reasons listed in clause 7 which are relevant to the object the subject of the application and whether or not for those reasons as elaborated in the categories and criteria prescribed in the Control List the object is of such importance that its loss will significantly diminish the cultural heritage of Australia.

${ }^{38}$ Re Truswell and Minister for Communications and the Arts (1996) 42 ALD 275, 295

${ }^{39}$ Re Truswell and Minister for Communications and the Arts (1996) 42 ALD 275, 295

${ }^{40}$ Re Truswell and Minister for Communications and the Arts (1996) 42 ALD 275, 294

${ }^{41}$ Re Truswell and Minister for Communications and the Arts (1996) 42 ALD 275, 295 
history, it conceived that while the VC was physically lacking as movable cultural heritage, the associated accounts and stories related to the VC would be recognised separately, as a discrete intangible:

[Its] value lies not in its tangible qualities but in its intangible. Its intangible qualities are twofold. The first is its symbolic quality. It symbolises courage, bravery, devotion to duty and self-sacrifice. It is public evidence of the very great value that we as a community place upon these qualities. A VC's intangible quality also lies in its power to direct the community's attention to an event or time in its history. This is a quality shared by objects such as the Old Gum Tree at Glenelg in South Australia and the Dig Tree in New South Wales which is associated with Burke and Wills' last expedition. ${ }^{42}$

The language of 'quality' used here reinforces the tribunal's reliance on the conventional bifurcated model of reading objects in art law. But its approach helped it deal with another problem - its origins: 'There is thus nothing Australian about its origins or its physical properties. The ... medals regarded as Australian have acquired their Australian identity solely through the nationality of their recipients. ${ }^{43}$ Unlike the court in the Australian content case, the tribunal was not shy about making a connection between of the object and the person who was able to give the object its meanings, its vibe. The tribunal seemed very pleased with its sophistry, in which this construction, or invention, of the intangible cleared the way to save this object from export.

But the tribunal still had to make a decision about the medals against $\mathrm{s} 10$ (6) (b). ${ }^{44}$ Armed with the newly minted 'intangible', and the characterisation of VCs as unique symbolic objects, ${ }^{45}$ the tribunal inevitably concluded that if the medals were to be exported, then they must be regarded as lost to Australia's cultural heritage, as an important or notable signpost to an outstanding Australian action in World War I and a symbol of heroic qualities which were exhibited in that action and which are themselves part of Australia's cultural heritage. ${ }^{46}$ Therefore, the decision under review was affirmed. ${ }^{47}$

\subsubsection{Retrieving the pre-iconographic and iconographic}

While the creation of the intangible 'worked' to achieve the outcome that conformed to the iconological, thus protecting the medal, the tribunal made a serious mistake in its interpretation both of the object and the legislation itself. It effectively cleaved the object and its iconology into two separate and distinct

\footnotetext{
${ }^{42}$ Re Truswell and Minister for Communications and the Arts (1996) 42 ALD 275, 295-296

${ }^{43}$ Re Truswell and Minister for Communications and the Arts (1996) 42 ALD 275, 296

${ }^{44}$ Re Truswell and Minister for Communications and the Arts (1996) 42 ALD 275, 296-297

${ }^{45}$ Re Truswell and Minister for Communications and the Arts (1996) 42 ALD 275, 296-297

${ }^{46}$ Re Truswell and Minister for Communications and the Arts (1996) 42 ALD 275, 297-298

${ }^{47}$ Re Truswell and Minister for Communications and the Arts (1996) 42 ALD 275, 298
} 
modes of reading, divorcing the iconological from the objective correctives found in the preiconographic and iconographic.

Yet despite the rupture, the tribunal had relied upon these two other factors throughout their reading of the VC. In terms of the pre-iconographic, the medal itself and the associated material relating to the circumstances surrounding the award of the medal were considered in detail in the judgment. From this point, the iconographic, the world of images, stories and allegories, was replete throughout the judgment. All the elements needed were at play, but because the tribunal could not see the object beyond its literal physical form, it could not bring these facets to play in reading the object. Here, it resulted in an iconological reading of the circumstances surrounding the award of the medal in which the tribunal drew on a Weltanschauung that perhaps saw much more in the relationship between war and the actions of its heroes and its relationship with the Australian identity than was actually there to see.

But it is the footprint, or trace of the law left behind by the decision is problematic. By treating the physical object as merely describable fact, it leaves the meanings of the object open for any interpretation at all, leaving a mawing gap to be filled in the juridical-aesthetic state of exception.

\subsection{THE ARCHIBALD PRIZE}

\subsubsection{An Artistic State of Exception}

The annual Archibald Prize for portraiture awarded by the trustees of the Art Gallery of New South Wales has been the subject of controversies and disputes since it was first awarded in 1921. Most of have been played out in the public arena, occasionally spilling into the courts, where, as the examples in this part of the chapter show, the judicial eye deploys the juridical-aesthetic state of exception to achieve the desired result by engaging in a strategic act of visual dysphasia. In short, the courts explicitly avoid looking at the images or visuals at all, and are thus grounded in an almost 'pre' preiconographic, to avoid seeing the obvious state of the images, as a device to protect the integrity of the trustees' aesthetic judgement against the terms of the trust document establishing the prize. In a sense, the prize, its associated competition and the legend of its benefactor are what acts as the iconology; and the pictures themselves are almost a side-show, rather than the main event.

The prize and its stipulations are constituted through the terms of the will of the late Mr J F Archibald. ${ }^{48}$ Archibald may well have approved of all the controversy surrounding the award of the prize because he was a controversial character himself. Born in 1850s Victoria, he co-founded the magazine The Bulletin

\footnotetext{
${ }^{48}$ Archibald was interested in art and he served as a Trustee for the Art Gallery of New South Wales. In 1900, he commissioned a portrait of the poet Henry Lawson and was so pleased with it, that he left money in his will for the prize. Art Gallery of New South Wales Archibald. Prize.09, History: Who was JF Archibald?

http://www.thearchibaldprize.com.au/history/jf_archibald
} 
in pre-Federation Australian in 1880 in order to advocate for an Australian nationhood, culture and identity in place of the series of separate British colonies located on the Australian continent. But he was inconsistent in the extreme. A champion of a racist white Australia policy through the pages of his publication, John Feltham Archibald chose to change his name from to Jules François, a curious French conceit indeed. His legacy looms large in Australia, and the prize and its reputation is legendary, even amongst people who have no real interest in visual culture. Winning the prize or having a picture included in the associated exhibition can make an artist's name.

But the legal controversies surrounding the prize are not, ostensibly at least, about art at all it is claimed, and instead are grounded in the drafting of the terms of the will. ${ }^{49}$ Yet it is the character of the visual that is central to the existence of the dispute, and the way in which that visual is created fundamental to the interpretation of the text of the will. With its references to 'best', 'portraiture', 'preferentially of some man or woman distinguished in Art Letters Science or Politics', 'painted' and 'picture', the award of the prize to aberrant images have been challenged by adherents of a traditional and conservative portraiture practice, when the prize has been awarded to images that challenge and confront the notion of portraiture, painting, and pictures.

\subsubsection{A human being painted by an artist}

The most celebrated (and perhaps most tragic) of the Archibald disputes occurred in 1943 (Eagle undated). The award of the prize to the acclaimed Australian artist, William Dobell of his friend and fellow artist, Joshua Smith, ${ }^{50}$ was challenged in court. ${ }^{51}$ Smith was disturbed by the representation of him, and he suffered a breakdown as a result of seeing his image as depicted by Dobell. ${ }^{52}$ Dobell's health was to suffer as well as a consequence of the legal dispute itself. Joshua Smith is depicted in a non-literal, mannerist style of a kind made famous by El Greco., that Dobell made his own. Joshua

\footnotetext{
${ }^{49}$ Clause 10 (a) of Archibald's will provides for the award of:
} an annual prize to be styled 'The Archibald Prize' for the best portrait preferentially of some man or woman distinguished in Art Letters Science or Politics painted by any Artist resident in Australasia during the twelve months preceding the date fixed by the Trustees for sending in the Pictures the Trustees to have the right to exhibit such winning Picture in the said Gallery for a space of not more than two months from the date so fixed. If during any such twelve months no competing picture shall in the opinion of the trustees be painted worthy of being awarded a prize then such income shall be accumulated and invested as hereinafter authorised with liberty to the trustees at any part of such period to purchase by such accumulations or part thereof any portrait that may have won any prize so given such exhibited or purchased prize to bear a label endorsed 'The Archibald Prize'." Extracted in Johansen v Art Gallery of NSW Trust [2006] NSWSC 577 [4]

${ }^{50}$ Australian Government Culture Portal: The Archibald Prize and Australia's premier art awards http://www.cultureandrecreation.gov.au/articles/archibald/

${ }^{51}$ Attorney-General v Trustees of National Art Gallery of NSW (1944) 62 WN (NSW) 212.

${ }^{52}$ Joshua Smith's parents wanted to buy the painting, but Dobell refused to sell it to them as he thought they may destroy it, selling it to Hayward instead. Eagle Joshua Smith himself won the prize the following year: Joshua Smith http://en.wikipedia.org/wiki/Joshua_Smith_(artist) 
Smith is shown with elongated neck and limbs, his face gaunt and linear. ${ }^{53}$ The style and character of the painting was impugned on the basis that it was not a portrait, but it was, instead, a caricature. The case against the trustees failed, because Roper $\mathrm{J}$ would not interfere with their decision because they had not demonstrated any mala fides in awarding the prize to Dobell. ${ }^{54}$ Despite this, Roper $\mathrm{J}$ engaged in an analysis of the image, in order to ascertain if the trustee were correct in their decision that the picture was a portrait:

The question of whether a particular picture is a portrait ... depends on the formation of opinions by the observer to whom it is propounded ... before this Court should interfere in the administration of the trust it must be satisfied that as a matter of objective fact and not of mere opinion the picture is not a portrait, so that the opinion formed by the trustees to the contrary is founded upon a wrong basis of fact and is not truly an opinion upon the question to which the minds of the trustees should have been directed. If this is the proper test, as I think it is, it is not necessary to interpret the word portrait in order to come to the conclusion that the suit fails; because the evidence is overwhelming, in my opinion, that at least there is a proper basis for forming an intelligent opinion that the picture in question is a portrait. ${ }^{55}$ (emphasis added)

This passage reveals that Roper $\mathrm{J}$ shifted his gaze to interrogate the notion of portrait as 'fact' rather as 'opinion', a device that allowed him to avoid considering whether Dobell's elongated visual style would be open to a challenge on the basis that the image was not a portrait. By shifting the judicial eye away from style to one grounded in a literal meaning of portrait as an image of 'a human being and painted by an artist', ${ }^{56}$ the court neatly avoided the problem of 'style', and the decision of the trustees vouchsafed. In short, the painting merely had to be: 'a pictorial representation of a person, painted by an artist. This definition connotes that some degree of likeness is essential and for the purpose of achieving it the inclusion of the face of the subject is desirable and perhaps also essential'. ${ }^{57}$ So if that bare minimum were achieved, then the picture would be a portrait, even if it might have fitted into another genre or type of painting such as the type proposed by the relators in the case, as a caricature or fantasy. In a final opinion on the character of the picture, he noted:

Finally I think that it is necessary to state my opinion on the claim that the picture cannot be included as a portrait because it is proper to classify it in another realm of art ... that

\footnotetext{
${ }^{53}$ In a coda that seems almost impossible to credit, in 1958 the picture was burnt in a fire at the home of its owner. In 1969, it was poorly restored and was effectively disowned by Dobell. Images of the restored painting and its state after the fire can be seen at: Archibald Controversy Painting http://www.artquotes.net/masters/williamdobell/portrait-of-an-artist.htm

${ }^{54}$ Attorney-General v Trustees of National Art Gallery of NSW (1944) 62 WN (NSW) 212, 214

${ }^{55}$ Attorney-General v Trustees of National Art Gallery of NSW (1944) 62 WN (NSW) 212, 214

${ }^{56}$ Attorney-General $v$ Trustees of National Art Gallery of NSW (1944) 62 WN (NSW) 212, 215

${ }^{57}$ Attorney-General v Trustees of National Art Gallery of NSW (1944) 62 WN (NSW) 212, 215
} 
would only establish to my mind that the fields are not mutually exclusive, because in my opinion it is in any event properly classed as a portrait. ${ }^{58}$

In a set of reasons replete with 'opinions', Roper $\mathrm{J}$ seemed to disown the criticism that he was engaged in aesthetic decision-making or intrusion into the realm of art. But though he used the word 'opinion' on numerous occasions, he had not engaged in any opinion-making at all that would, to his mind, constitute aesthetic decision-making. By simply treating the image as a fact - a human being painted by an artist that bore some resemblance to that person - Roper $\mathrm{J}$ read the image to identify a known human - an exercise within conventional legal analysis of 'fact finding'. In doing so, whether he meant to do so or not, he engaged in one aspect of Panofsky's tripartite system, namely, the pre-iconographic practice of identification of the image, leaving its meaning and value open to radical interpretations that are the stuff of the juridical-aesthetic state of exception .

\subsection{It is hard to think how it could be otherwise}

While the interpretative openness of the juridical-aesthetic state of exception was used in the Dobell case to achieve the desired outcome, the most recent Archibald Prize dispute some 60 years later is an exemplary rendering of its use, in which images are construed as textually impotent to achieve the desired legal outcome. In 2004, the award of the prize by the trustees was impugned by a rival artist who asserted that the portrait had not been 'painted' as required under the terms of the prize trust. The winning portrait by artist Craig Ruddy of the indigenous actor David Gulpilil was created from a mass of lines, which appeared to have been 'drawn' rather than 'painted'. ${ }^{59}$ Relying on the reasoning in the Dobell case, ${ }^{60}$ Hamilton $\mathrm{J}$ found that the trustees had awarded the prize to a portrait that had been 'painted'. There were no grounds on which to find that they had not properly exercised their duties, so the prize could not be interfered with. ${ }^{61}$

While reaching the same conclusion as Roper $\mathrm{J}$, Hamilton $\mathrm{J}$ radically avoided entering into a reading of the visual in order to do so. This time, the case centred on the techniques and media used to create the portrait, and not the mode of representation concerned. And because of this, it seems, Hamilton $\mathrm{J}$ felt obliged to observe that: 'The Court is in no way concerned with the merits of the portrait ... The sole issue for the Court as a court of equity is whether the award was in breach of the terms of the charitable trust in the execution of which the first defendant awarded the prize ${ }^{62}$ I suspect he realised that there was more to visual than the judgment could bear to see, because the technique used to create it was that of 'drawing', making it impossible for the image to be read in Roper J's terms, as 'human being painted by an artist'. If he had looked too closely, he could only have decided the image was drawn,

\footnotetext{
${ }^{58}$ Attorney-General v Trustees of National Art Gallery of NSW (1944) 62 WN (NSW) 212, 215

${ }^{59}$ The image may be seen at Australian Government Culture Portal: The Archibald Prize and Australia's premier art awards http://www.cultureandrecreation.gov.au/articles/archibald/

${ }^{60}$ Johansen v Art Gallery of NSW Trust [2006] NSWSC 577 [20]

${ }^{61}$ Johansen v Art Gallery of NSW Trust [2006] NSWSC 577 [31]

${ }^{62}$ Johansen v Art Gallery of NSW Trust [2006] NSWSC 577 [3]
} 
and not painted. Thus in an extraordinary interpretative gesture at the conclusion of the judgment, Hamilton $\mathrm{J}$ demurred from making any finding of fact about the visual at all:

I do not intend to proceed to a judicial finding of fact as to whether or not the work is 'painted'. I have already commented that there is a certain appearance of strangeness in courts making determinations concerning the qualities of works of art. That matter is better left to those involved in the art world ... or, for that matter to any 'intelligent' viewer, using the word 'intelligent' in the manner in which it was employed by Roper J. Since a judicial finding on this subject matter is not necessary for the determination of the proceedings, I think it better not made. ${ }^{63}$

But throughout the judgment, Hamilton $\mathrm{J}$ had to consider what was obvious to anyone looking at the image. Accepting the position of the (losing) plaintiffs and Roper $\mathrm{J}$ that "painted" conveys the meaning that the portrait must be a painting, not a work made by some other means', ${ }^{64}$ Hamilton $\mathrm{J}$ took 'into account the impression the portrait creates on the viewer' to decide that he really couldn't decide if this was a painting or a drawing: ${ }^{65}$

minds may well differ as to whether, if the picture must be placed in a single category, that category should be "painting" or "drawing". But, in view of those matters, I find it impossible on any objective basis to exclude the portrait from the category of a work which has been "painted", which is the real issue here ... whichever characterisation was made, it was a matter of judgment or opinion. ${ }^{66}$

The impression, of course, is that the painting's 'vibe', its feeling, is that of a painting. But facing the facts that he decided not to find, there is no question that Hamilton $\mathrm{J}$ would have had to have seen a drawing. So he radically avoided looking at the image at all, other than listing and describing a preponderance of elements that constituted the contents of the canvas - how could tangled hair be represented other than the ideational of lines - leaving an impression that he had seen what to his eyes was very much a drawing:

The portrait depicts Mr Gulpilil's head, shoulders and upper torso. It appears, from the evidence, that Mr Gulpilil has a mass of tangled hair. This is represented in the portrait by a mass of lines. It is hard to think how it could be otherwise. Close examination of the portrait shows the presence of many lines, some appearing almost as line on line, as has been said, in the depiction of Mr Gulpilil's face and body. On the other hand, there are present in the face and parts of the body substantial areas which appear as solid masses

\footnotetext{
${ }^{63}$ Johansen v Art Gallery of NSW Trust [2006] NSWSC 577 [32]

${ }^{64}$ Johansen v Art Gallery of NSW Trust [2006] NSWSC 577 [25]

${ }^{65}$ Johansen v Art Gallery of NSW Trust [2006] NSWSC 577 [29]

${ }^{66}$ Johansen v Art Gallery of NSW Trust [2006] NSWSC 577 [29] - [30]
} 
of black. The portrait is supported upon wallpaper, which appears to have a yellow pattern on a light background. Despite this colouring in the wallpaper, the principal impression of the portrait is that it is in black or shades of grey. ${ }^{67}$

Hamilton $\mathrm{J}$ chose to avoid Panofsky's pre-iconographic phase by electing not to read the primary or natural subject matter of the visual, instead only seeing lines and impressions on a canvas. Those lines and impressions were dangerous to the interpretation of the law under consideration, for these would take the image into the realm of drawing and not painting, thus leaving the award of the prize invalid and void. But this reading of the lines without more is, in Panofsky's schema (and in the terms of the will), a nonsense, for no image, no portrait that is painted is comprised of its elements at the expense of the whole. The reliance on the indicia certa, the lines and methods used to create the image, meant that Hamilton $\mathrm{J}$ was painted into a corner, as it were, leaving the image disassembled into its elemental parts which could not be retrieved. If on the other hand the Panofskian schema were employed, the court would have seen much more than lines on a canvas, and it would have been able to read the visual intuitively. Even though a synthetic intuition, Panofsky's iconological approach would require a court to see what was actually there to be seen as a whole. But this would require an acceptance that law's reliance on, and belief in the clarity provided by the verifiable and identifiable is more radically uncertain, nihilistic even, that the visual as vibe. Instead, Hamilton $\mathrm{J}$ radically sees nothing, resulting in a paradoxical visual nihilism, by preferring the iconology of the law as a precise and perfected form of viewing the image instead of accepting the iconography or iconology of the visual or the image.

\subsection{Conclusion}

This aporetic gesture by Hamilton $\mathrm{J}$ is an application of the juridical-aesthetic state of exception in its archest form, in which everything that is visible to the eye is invisible to the court, in order to achieve the desired legal outcome in the case: that the decision of the trustees should not be interfered with. But this process of avoidance shows that it is impossible for law to do what it claims, and not engage with the visual, as law must read the images given to it to interpret and consider. It is a mere empty gesture to suggest that law leaves the reading and interpreting of visuals and images to others. But even if the courts were to be convinced that guidance from interpretative schemas, such as Panofsky's, would assist them in the process of dealing with the visuals and images that so vex them, they would find ways to avoid its tests and techniques, because it is just so legally useful to pick and choose from the mass of elements and stories that sit in and around canvases, lyrics, music, and film, instead of accepting the potentially truth claims that are located in the vibe. So I suspect that the courts would always find a way to occlude what they didn't want to see, and see what they want, leaving visuals and images in a perpetual legal state of exception. Do you see what I see?

\footnotetext{
${ }^{67}$ Johansen v Art Gallery of NSW Trust [2006] NSWSC 577 [6]
} 


\section{References}

\section{Books}

Darian-Smith, E. (1999), Bridging Divides: The Channel Tunnel and English Legal Identity in the New Europe, Berkeley: University of California Press.

Douzinas, C., Warrington, R., McVeigh, S. (1991), Postmodern Jurisprudence: The Law of Text in the Texts of Law, London: Routledge.

Douzinas, C., Nead, L. (1999), Law and the Image: the Authority of Art and the Aesthetics of Law, Chicago: The University of Chicago Press.

Dworkin, R. (1986), Law's Empire, Cambridge, Mass.: The Belknap Press of Harvard University Press.

Goodrich, P. (1996), Law in the Courts of Love: Literature and Other Minor Jurisprudences, London: Routledge.

Griffiths, T. (1996), Hunters and Collectors: The Antiquarian Imagination in Australia, Cambridge: Cambridge University Press.

Leiboff, M., Thomas, M. (2009), Legal Theories: Contexts and Practices, Pyrmont: Law Book Co.

MacNeil, W. (2007), Lex Populi: The Jurisprudence of Popular Culture, Stanford: Stanford University Press.

Panofsky, E. (1955), Meaning in the Visual Arts: Papers in and on Art History, New York: Doubleday.

Panofsky, E. (1972), Studies in Iconology: Humanistic Themes in the Art of the Renaissance, New York: Harper \& Row.

Preziosi, D. (2009), The Art of Art History: A Critical Anthology $2^{\text {nd }}$ ed., Oxford: Oxford University Press. Seymour, M. (2008), Thirteen Tonne Theory: Life inside Hunters and Collectors, Melbourne: Viking.

\section{Book Chapters}

Bann, S. (2003), „Meaning/Interpretation”, in: R. Nelson, R. Shiff (eds.), Critical Terms in Art History $2^{\text {nd }}$ ed., Chicago: University of Chicago Press, $128-142$.

Baudelaire, C. (1857), „L'albatros”, in Les Fleurs du Mal, Spleen et ldéal No 2.

Eagle, M. (Undated), „Dobell, Sir William (1899 - 1970)”, in: Australian Dictionary of Biography Online Edition, http://adbonline.anu.edu.au/biogs/A140013b.htm, accessed 18 December 2009.

Potts, A. (2003), „Sign”, in: R. Nelson, R. Shiff (eds.), Critical Terms in Art History $2^{\text {nd }}$ ed., Chicago: University of Chicago Press, 20 - 34.

Timmermann, A. (2001), „Iconology", in H. Brigstocke (ed.): The Oxford Companion to Western Art, Oxford Reference Online, http://www.oxfordreference.com, accessed 8 January 2010.

\section{Journal articles}

Bal, M., Bryson, N. (1991), "Semiotics and Art History.", Art Bulletin 73.2, 174-208. 
Barron, A. (2006), “Copyright Law's Musical Work”, Social \& Legal Studies 15, 101 - 127.

Hasenmueller, C. (1978), "Panofsky, Iconography and Semiotics", The Journal of Aesthetics and Art Criticism 36, $289-300$.

Hasenmueller, C. (1981), "The function of art as 'iconic text': An alternative strategy for a semiotic of art", Semiotica 36.1-2,135-152.

Hasenmueller, C. (1989), "A picture is worth a thousand words: How we talk about image", Semiotica 73.3-4, 275-300.

Kirby, M. (2006), "Hanging Judges and the Archibald Prize", Media and Arts Law Review 11.3, 300 309.

Leiboff, M. (2001), "clashing things", Griffith Law Review 10, 294-316.

Leiboff, M. (1998), "Football, Meatpies, Kangaroos and Holden Cars? The Arts and Cultural Implications of Project Blue Sky v ABA", Media and Arts Law Review 3.2, 135-145.

Leiboff, M. (2007), "Law's empiricism of the object: how law recreates cultural objects in its own image", Australian Feminist Law Journal 27, 23 - 50.

Leiboff, M. (2009), "Art, actually! The courts and the imposition of taste', Public Space: The Journal of Law and Social Justice", 3/1, 1-23,

http://epress.lib.uts.edu.au/ojs/index.php/publicspace/article/viewFile/1212/1210, accessed 1 December 2009.

Levi, N. (2007), "Carl Schmitt and the Question of the Aesthetic", New German Critique 34, 27 - 43.

Mount, H. (2006), "The Monkey with the Magnifying Glass: Constructions of the Connoisseur in Eighteenth-Century Britain", Oxford Art Journal 29, 167 - 173.

Pettersson, H. (2001), "Panofskys tredje nivå och den kritiska historiografins syfte (Summary in English: Panofsky's Third Level and the Purpose of Critical Historiography)", Konsthistorisk Tidskrift/Journal of Art History 70.1, $55-65$.

Sherwin, R. (2007), "Passing On: Images: Law, metaphysics, and the new iconoclasm", Law/Text/Culture 11, 70 - 105.

\section{Conference Papers}

Leiboff, M. (2006), "Tristram Shandy and the limits of copyright law; Or, is a blank page an idea?", refereed paper delivered at PASSAGES: law, aesthetics, politics, 13-14 July 2006 Melbourne Australia, available online via www.law.unimelb.edu.au/cmcl, accessed 1 December 2009.

\section{Cases}

Attorney-General v Trustees of National Art Gallery of NSW (1944) 62 WN (NSW) 212.

Johansen v Art Gallery of NSW Trust [2006] NSWSC 577

Project Blue Sky v Australian Broadcasting Authority (1998) 194 CLR 255; [1998] HCA 28 
Re Truswell and Minister for Communications and the Arts (1996) 42 ALD 275

\section{Case Transcripts}

Project Blue Sky Inc and ORS v Australian Broadcasting Authority S219/1996 [1997] HCATrans 135 (11 April 1997) http://www.austlii.edu.au/cgi bin/sinodisp/au/other/HCATrans/1997/135.html Project Blue Sky Inc and ORS v Australian Broadcasting Authority S41/1997 [1997] HCATrans 302 (29 September 1997) http://www.austlii.edu.au/cgi-bin/sinodisp/au/other/HCATrans/1997/302.html

\section{Legislation and treaties}

Broadcasting Act 1942 (Cth)

Broadcasting Services Act 1992 (Cth)

Protection of Movable Cultural Heritage Act 1986 (Cth)

Convention on the Means of Prohibiting and Preventing the Illicit Import, Export and Transfer of Ownership of Cultural Property 17 November 1970, Paris

\section{Newspapers and magazines}

Conomy, T. (2009), "Sound Advice”, The Sydney Morning Herald, Monday 16 November, 12.

Forster, R. (2008), "The Uncorking: Mark Seymour's 'Thirteen Tonne Theory”, The Monthly, 34 May 2008, http://www.themonthly.com.au/music-robert-forster-uncorking-mark-seymour-s-thirteen-tonnetheory-913, accessed 29 September 2009.

\section{Online document}

Anonymous. (Undated), "Archibald Controversy Painting", http://www.artquotes.net/masters/williamdobell/portrait-of-an-artist.htm, accessed 14 August 2008.

Anonymous. (Undated), "Archibald Prize”, http://en.wikipedia.org/wiki/Archibald_Prize, accessed 14 August 2008.

Anonymous. (Undated), “Joshua Smith”, http://en.wikipedia.org/wiki/Joshua_Smith_(artist), , accessed 14 August 2008.

Anonymous. (Undated), "The Castle", http://en.wikipedia.org/wiki/The_Castle (film), accessed 20 May 2009.

Anonymous. (Undated), "The Castle Constitution Vibe", http://www.youtube.com/watch?v=ITUSZ6LRHrk, accessed 1 September 2009.

Art Gallery of New South Wales. (Undated), "Archibald.Prize.09 History", http://www.thearchibaldprize.com.au/history, accessed 19 November 2009.

Art Gallery of New South Wales. (Undated), "Who was JF Archibald?", http://www.thearchibaldprize.com.au/history/jf_archibald, accessed 19 November 2009. 
Art Gallery of New South Wales. (Undated), "Controversy and Debate", http://www.thearchibaldprize.com.au/history/controversy, accessed 19 November 2009.

Australian Government Culture Portal. (Undated), "The Archibald Prize and Australia's Premier Art Awards", http://www.cultureandrecreation.gov.au/articles/archibald, accessed 19 November 2009.

Beckingham, B. (2000), 'The Castle' in: The Oz Film Database, http://wwwmcc.murdoch.edu.au/ReadingRoom/film/dbase/2000/Castle.html, accessed 20 May 2009.

Hunters \& Collectors, Seymour, M. (1982), "Talking to a Stranger".

http://www.humanfrailty.com.au/songs/talking_to_a_stranger.htm\#lyrics, accessed 30 July 2009.

Hunters \& Collectors, Seymour, M. (1987), "Do You See What I See?",

http://www.humanfrailty.com.au/songs/do_you_see_what_i_see.htm, accessed 29 December 2008.

Hunters \& Collectors, Seymour, M. (1988), "Promotional Video: 'Do You See What I See?”, http://www.youtube.com/watch?v=S0XQCNEY3PM, accessed 20 December 2008.

Hunters \& Collectors, Seymour, M. (Undated), "Natural Selection, What's a Few Men?" (alternative title "Fate"), http://www.humanfrailty.com.au/albums/wafm_fate.htm, aaccessed 30 July 2009.

Moat, J. (Undated), "Talking to a Stranger (1966)" in: British Film Institute, BFI Screenonline, htttp://www.screenonline.org.uk/tv/id/499298/index.html, accessed 20 December 2008. 